DOI https://doi.org/10.30525/978-9934-26-000-1-22

\title{
ІНСТРУМЕНТИ ФАКТЧЕКІНГУ ПРИ ВИЯВЛЕННІ ФЕЙКОВОЇ ІНФОРМАЦІЇ В СОЦІАЛЬНИХ МЕДІА
}

\author{
Татарчук Д. О. \\ студентка III курсу \\ Інститут журналістики Київського університету \\ імені Бориса Грінченка \\ м. Київ, Україна
}

Мета дослідження: визначити найбільш актуальні інструменти фактчекінгу при виявленні фейкової інформації в соціальних медіа.

Актуальність дослідження зумовлена подальшим активним розвитком соціальних медіа як площини для маніпулювання свідомістю споживачів інформації, нагальна необхідність у формуванні в них свідомого ставлення до інформації, навчання якомога ширших кіл споживачів застосування інструментів перевірки інформації й, відповідно, визначення найбільш дієвих інструментів.

Президент України Володимир Зеленський в інтерв'ю «ІнтерфаксУкраїна» актуалізував боротьбу 3 фейками в інформаційному полі, проілюструвавши серйозність цієї проблеми. Так само 27.03.2020, як повідомила організація «ВоксУкраїна», «соціальна мережа Facebook запустила боротьбу з фейками в Україні, 27 березня. Таким чином, «Проєкти \#VoxCheck та @StopFakingNews стали його партнерами в цій боротьбі і тепер можуть маркувати фейкову інформацію у ФБ, щоб українці відразу бачили, де \#зрада та \#фейк», - інформує спільнота у твітері». Отже, актуалізація теми обумовлена кількома напрямками: суспільною важливістю та необхідністю вміти селектувати й аналізувати інформацію; увагою з боку влади, що свідчить про значний вплив фейків на функціонування держави; посиленими заходами з боку платформ, що використовуються для творення, поширення та споживання інформації.

Методи дослідження: пошук та відбір важливих кейсів, котрі ілюструють обрану тему, аналіз авторитетних праць, визначення найцікавішого й систематизація, проведення онлайн-опитування.

Tеоретична цінність дослідження полягає в тому, що вона певним чином систематизує уявлення про фейк як явище сучасного інформаційного простору.

Практична цінність дослідження в розробці та практичній перевірці інструментів фактчекінгу при перевірці правдивості інформації в соціальних медіа.

У роботі ми керуємося такими робочими визначеннями поняття «фейк». 1. М. Кіца: «Термін «фейкові новини» Вікіпедія трактує як 
повністю або частково вигадана інформація про суспільні події, явища, певних осіб, яка подається у ЗМІ під виглядом справжніх журналістських матеріалів» [1, с. 283]. 2. О Саприкін: «Фейк - дезінформація, умисне викривлення тих чи інших явищ, фактів, подій, причому зловмисність такого викривлення старанно приховується; навпаки, фейкове повідомлення містить усі ознаки правдивого повідомлення, що дає можливість впливу на певну аудиторію завдяки використанню симулякрів» [2, с. 36].

Науковці з Університету Західного Онтаріо виділяють п'ять типів фейків: «навмисно створені фейки; жарти, сприйняті як правда; масштабні містифікації; навмисно однобоке висвітлення подій; історії, в яких «правда» $\epsilon$ суперечливою (наприклад, терорист для одних $\epsilon$ борцем за свободу для інших)» [3].

В інформаційному просторі України можна знайти приклади всіх типів фейкової інформації: 1. навмисно створені фейки. До таких можна, на нашу думку, зарахувати фейк про кульові блискавки в Україні, який поширився у 2018 році: «У середу, 1 серпня, 3 14-ї до 17-ї години більше 160 3МI Херсонської, Донецької, Запорізької, Луганської та Миколаївської областей отримали на редакційні адреси прес-реліз (двома мовами) під назвою «Шаровые молнии в Запорожской (Николаевской, Луганской еtс.) области в августе - пресс-релиз» зі скриньки nasa.nasaukraine@gmail.com»». Насправді це був експеримент, який у результаті провалили навіть авторитетні 3МI. 2. жарти, сприйняті як правда. До цього виду можна зарахувати фейк про хлопця зі світової олімпіади мемів, створений менеджером спецпроектів AIN.UA Олександром Лінником. Як зазначив сам творець, це був жартівливий експеримент. 3. масштабні містифікації. Сюди ми можемо зарахувати істинність існування Шекспіра. Існує чимало статей, які аналізують, чи був такий письменник взагалі, оскільки факти біографії не збігаються 3 історичними даними та $є$ чимало запитань до цієї постаті. 4. навмисно однобоке висвітлення подій. Вважаємо, що це прийом пропаганди. Найяскравішими прикладами можна вважати 3МІ сучасних країн, що мають ознаки тоталітарності (Білорусь, Росія тощо). Приклад: у 2010 Володимир Путін заявив, що Росія перемогла би в Другій світовій і без України. Такий меседж швидко підхопили ЗМІ, ілюструючи його «правдивість» і не висвітлюючи роль України у масштабному збройному конфлікті. Хоча сьогодні $є$ чимало й менш скандальних випадків. Кожного разу, коли ілюструється лише один погляд у новинному сюжеті, це маніпуляція. 5. історії, в яких «правда» с суперечливою (наприклад, терорист для одних с борцем за свободу для інших). Такою $\epsilon$, наприклад, постать Степана Бандери навіть у межах України. Частина вважає його героєм, а частина - бандитом (аргументи: він співпрацював 3 німцями й СРСР). Що вже й казати, про двозначність постаті за кордоном (наприклад, у РФ). 
На первинному етапі, ще до застосування інструментів фактчекінгу, ми пропонуємо звертати увагу на кількість покликань у публікації, авторитетність осіб, на яких покликається автор, не реагувати емоційно (саме так працює фейк: б'є на емоції. Намагайтеся знайти «червоні маркери», які змушують емоційно реагувати; акими словами може бути мова ненависті, що передбачає стереотипні чи/та образливі лексеми. Приклад: «сєпари», «жиди», «нелюди» тощо), перевіряти інформацію в кількох джерелах. А ту, яку важко перевірити (як у випадку із Шекспіром, важливо просто не сприймати одразу за чисту монету).

При аналізі матеріалів, представлених у соціальних медіа, шляхом практичного застосування інструментів фактчекінгу необхідно чітко визначити перелік джерел первинної інформації, необхідних для перевірки саме цієї новини (сайти офіційних організацій, документи відкритого доступу, виступи посадовців, декларації тощо).

У практичній частині дослідження здійснено розгорнутий аналіз низки повідомлень у соціальних медіа із застосуванням інструментів фактчекінгу, що дозволило зробити загальні висновки про те, що для аналізу важливо обрати стратегію, яка включала би кілька етапів: етап особистого сумніву, оцінка цілісного матеріалу, пошук деталей, аналіз частин матеріалу, перевірка за допомогою певних інструментів/ресурсів, загальних власний висновок. Дуже важливо комплексно аналізувати матеріали, особливо якщо вони мультимедійні, оскільки це дозволяє використати весь потенціал інструментарію фактчекінгу й визначити ступінь спотворення інформації в матеріалі.

У цілому такі дослідження мають велику перспективу, оскільки фахівцям у галузі інформації потрібно грунтовно працювати над поглибленням медіаграмотності населення з метою послаблення маніпулятивного тиску на широку маси споживачів інформац.

\section{Література:}

1. Кіца М.О. Фейкова інформація в українських соціальних медіа: поняття, види, вплив на аудиторію. Соціальні комунікації, 2016. URL: http://nz.uad.lviv.ua/static/media/1-52/36.pdf.

2. Саприкін О.А. Фейк як інструмент інформаційної війни проти України. Київ. 2016.

3. Сайт ГО «Детектор-медіа». URL: https://ms.detector.media/ mediaanalitika/post/20242/2017-12-20-fantastichni-feiki-i-de-ikh-shukatiyak-fake-news-stalo-ponyattyam-roku/ 